\title{
SECURITIES EXCHANGE ACT: DEFRAUDED ISSUER HAS PRIVATE RIGHT OF ACTION UNDER SECTION IO(b)
}

$\mathrm{I}_{\mathrm{N}}$ Hooper v. Mountain States Sec. Corp., ${ }^{1}$ the Court of Appeals for the Fifth Circuit joins the Courts of Appeals for the Second, ${ }^{2}$ Third $^{3}$ and Ninth ${ }^{4}$ Circuits in holding that a violation of section $\mathrm{IO}(\mathrm{b})$ of the Securities Exchange Act of $1934^{5}$ and rule $\mathrm{X}-\mathrm{IOB}-5$, promulgated thereunder, gives rise to a private right of action. ${ }^{6}$ In order to hold for plaintiff in this case, however, the court was required to determine that a defrauded seller need not have the status of "investor" to come within the purview of section $\mathrm{IO}(\mathrm{b})^{7}$ of the act and that a corporation defrauded in the issue of its own stock is a "seller" within the meaning of rule X-roB-.$-^{8}$

\footnotetext{
${ }_{282}$ F.2d 195 (5th Cir. 1960).

${ }^{2}$ Fischman v. Raytheon Mfg. Co., 188 F.2d 783 (2d Cir. 1951).

${ }^{3}$ Slavin v. Germantown Fire Ins. Co., 174 F.2d 799 (3d Cir. 1949) (dictum).

4Errion v. Connell, 236 F.2d 447 (9th Cir. 1956); Fratt v. Robinson, 203 F.2d 627 (9th Cir. 1953).

" 48 Stat. 88x (x934), 15 U.S.C. \& 78 (1958).

${ }^{6}$ Kardon v. National Gypsum Co., 69 F. Supp. $5 \times 2$ (E.D. Pa. 1946), was the first case to rule squarely on the isssue of a civil remedy under $\S$ ro(b) and rule X-roB-5. Accord, Smith v. Bear, 237 F.2d 79 (2d Cir. 1956); Errion v. Connell, 236 F.2d 447 (9th Cir. 1956); Fratt v. Robinson, 203 F.2d 627 (9th Cir. 1953); Fischman v. Raytheon Mfg. Co., I88 F.2d 783 (2d Cir. x95 I); Slavin v. Germantown Fire Ins. Co., 174 F.2d 799 (3d Cir. 1949) (dictum); Mills v. Sarjem Corp., 133 F. Supp. 753 (D.N.J. 1955); Thiele v. Shields, $33 \times$ F. Supp. 416 (S.D.N.Y. 1955); Northern Trust Co. v. Essanes Theatres Corp., 103 F. Supp. 954 (N.D. Ill. 1952); Speed v. Transamerica Corp., 99 F. Supp. 808 (D. Del. 1951); Robinson v. Difford, 92 F. Supp. 145 (E.D. Pa. 1950); Osborne v. Mallory, 86 F. Supp. 869 (S.D.N.Y. 1949); Hawkins v. Merrill Lynch, Pierce, Fenner \& Beane, 85 F. Supp. xo4 (W.D. Ark. 1949); Stella v. Kaiser, 82 F. Supp. 301 (S.D.N.Y. 1948); Montaguc v. Electronic Corp. of America, 76 F. Supp. 933 (S.D.N.Y. x948); Fry v. Schumaker, 83 F. Supp. 476 (E.D. Pa. 1947); Acker v. Schulte, 74 F. Supp. $68_{3}$ (S.D.N.Y. 1947).

"It shall be unlawful for any person, directly or indirectly, by use of any means or instrumentality of interstate commerce or of the mails, or of any facility of any national securities exchange$* * *$
}

(b) To use or employ, in connection with the purchase or sale of any security registered on a national securities exchange or any security not so registered, any manipulative or deceptive device or contrivance in contravention of such rules and regulations as the Commission may prescribe as necessary or appropriate in the public interest or for the protection of investors." 48 Stat. $89 x$ (1934), 15 U.S.C. $\S 78 j(b)$ (1958).

${ }^{8}$ ' $I t$ shall be unlawful for any person, directly or indirectly, by the use of any means 
Plaintiff, trustee in bankruptcy for Consolidated American Industries, Inc., brought suit for damages and an accounting in the Middle District of Alabama alleging that defendants had fraudulently obtained Consolidated's stock in a scheme perpetrated through the use of interstate communications. ${ }^{9}$ Plaintiff sought to establish by these allegations a violation of the Securities Exchange Act which would entitle him to extra-territorial service of process under the act. ${ }^{10}$ The district court viewed the factual allegations as sufficient to charge a fraudulent scheme in the issuance of the stock. However, it dismissed the complaint in reliance on a recent Second Circuit decision, Howard v. Furst, ${ }^{11}$ which held that specific corporate remedies in the Securities Exchange Act

or instrumentality of interstate commerce, or of the mails, or of any facility of any national securities exchange,

(a) To employ any device, scheme, or artifice to defraud.

(b) To make any untrue statement of a material fact or to omit to state a material fact necessary in order to make the statements made, in the light of the circumstances under which they were made, not misleading, or

(c) To engage in any act, practice, or course of business which operates or. would operate as a fraud or deceit upon any person, in connection with the purchase or sale of any security." I7 C.F.R. § 240. rob-5 (1949).

'The facts as alleged by plaintiff, and deemed to be established for the purposes of ruling upon defendants' motion to dismiss, tended to show that defendants, former officers and the general counsel of Consolidated, had formed a vehicle corporation througll which spurious contract rights were to be transferred for Consolidated stock. The shares were procured from Consolidated's transfer agent with falsely certified corporate resolutions approving their transfer to the vehicle corporation. Before this transaction was completed, the vehicle corporation was dissolved, and new stock was issued in the name of its distributees. These shares were then sold by defendants to individual investors throughout the world.

${ }^{10}$ Section 27 of the act provides that any action arising under the statute may be brought in "the district wherein any act or transaction constituting the violation occurred ... or in the district wherein the defendant is found or is an inhabitant or transacts business, and process . . . may be served in any other district of which the defendant is an inhabitant or wherever the defendant may be found." 48 Stat. 902 (1934), I5 U.S.C. $\$ 78 \mathrm{aa}(1958)$.

${ }_{11} 238$ F.2d 790 (2d Cir. 1956), cert. denied, 353 U.S. 937 (1957). There, a shareholder brought suit against the corporation and its directors to enjoin voting of proxies obtained by allegedly fraudulent proxy statements and to recover damages on behalf of the corporation for wasting its assets. In affirming the district court's dismissal of the complaint, the Court of Appeals for the Second Circuit stated: "[T] he statute authorizes the formulation of rules and regulations in the public interest or for the protection of investors.' There is literally nothing to support the view that any substantive rights were created for the benefit of the corporation. The Securities Exchange Act of 1934 is a comprehensive piece of legislation of wide scope. Significantly, where it was intended to create a right of action in favor of the issuer corporation, the statute makes express provision therefor." 238 F.2d at 793 . 
precluded the existence of a substantive civil right of shareholders to bring a derivative action under section $\mathrm{I}_{4}(\mathrm{a})^{12}$ and its implementing rule $\mathrm{X}-\mathrm{I} 4 \mathrm{~A}-\mathrm{g} .^{13}$ In reversing the district court, the Fifth Circuit Court of Appeals limited Howard $v$. Furst to actions involving the solicitation of proxies under section I4(a) of the act. ${ }^{14}$

Section Io(b) of the 1934 act is inoperative in the absence of implementing rules. It contains no specific provision for civil liability, but makes unlawful the use of any deceptive device or contrivance in connection with the purchase or sale of any security in contravention of rules and regulations prescribed by the Commission "in the public interest or for the protection of investors." Narrowly interpreted, this language would appear to sanction a right of action only when the seller or purchaser is an "investor." In Hooper, defendants argued that because the corporation could not be an investor in its own unissued stock, it was not a member of the class intended to be protected by the statute and, therefore, had no private right of action. However, the court considered the test of appropriateness to be founded on two bases, each of which justified the implementing rule. The inability of plaintiff to assert a claim as an injured "investor" did not foreclose his right to proceed under the alternative basis, as an injured member of the class whose interests the statute was enacted to protect "in the public interest."15 Recognizing that the broad purpose of this legislation is to protect those engaging in securities transactions by deterring

\footnotetext{
12 "It shall be unlawful for any person, by the use of the mails or by any means or instrumentality of interstate commerce or of any facility of any national securities exchange or otherwise to solicit or to permit the use of his name to solicit any proxy or consent or authorization in respect of any security (other than an exempted security) registered on any national securities exchange in contravention of such rules and regulations as the Commission may prescribe as necessary or appropriate in the public interest or for the protection of investors." 48 Stat. 895 (r934), ${ }_{5}$ U.S.C. $\$ 78 n(a)$ (1958).

${ }_{13} 17$ C.F.R. $\$ 240.14^{a-9}$ (1949).

${ }^{14}$ "We find it unnecessary and undesirable to undertake any criticism either of that decision or the comments made with respect to a civil action brought as a stockholders' derivative suit alleging a violation of $\S \mathrm{I}_{4}(\mathrm{a})$ and Rule X-r $4 \mathrm{~A}-9$ on solicitation of proxies. We decline, as we think that Court would, to read into its language a holding that a corporation injured by a sale or purchase of securities has no private right of action under $\S$ ro(b) and X-roB-5." 282 F.2d at 203.

. ${ }^{26}$ The general rule is that no civil liability is incurred for violation of a statute enacted to protect the interests of the general public. Sce Restatement, TorTs $\S 288$ (1935). Thus, plaintiff must show a special injury resulting from the violation if he is to assert that the statute was not simply enacted for the protection of the public generally.
} 
fraudulent schemes perpetrated through channels of interstate commerce, the court concluded: "[A] person who parts with stock owned by him as the result of fraudulent practices wrought on him by his purchaser sustains an adverse impact that differentiates him from the damage suffered by the public generally."16

Having determined that the corporation was a person whose interests section $I O(b)$ was enacted to protect, the court next faced the question of whether its claim came within the scope of rule X-roB-5. In order to state a claim under the rule, it must be shown that defendant has engaged in fraudulent conduct in connection with a purchase or sale of a security "by the use of any means or instrumentality of interstate commerce, or of the mails, or of any facility of any national securities exchange."17 The plaintiff's allegations were clearly sufficient to charge a fraudulent scheme within the meaning of the rule; $;^{18}$ the corporation was a "person" under the statute, ${ }^{19}$ and the stock issued by it was a "security."20 The only jurisdictional question remaining was whether the transaction resulting in the issuance of Consolidated's stock was a "sale."12 Defendants obtained the stock from Consolidated's transfer agent with falsely certified corporate resolutions purporting to approve exchange of the stock in consideration for contract rights possessed by defendants. Before the transaction, this stock had an economic value to Consolidated equal to the proceeds that could be realized on issue. After the transaction Consolidated no longer had the stock, although apparently it had acquired contract rights represented to be commensurate in value. Since section 3 (a) (I4) ${ }^{22}$ provides that the terms "sale" and "sell" shall include any contract to sell "or otherwise dispose of [securities]," the court concluded: "If this is not a sale in the strict common law traditional sense, it certainly amounted to an arrangement in which Consolidated 'otherwise dispose[d] of' its

\footnotetext{
${ }^{10} 282$ F.2d at 202.

${ }_{17}{ }_{17}$ C.F.R. 240.1 0b-5 (1949).

18 282 F.2d at 200 . The sufficiency of the allegations of fraud under FED. R. Civ.

P. 9 was not challenged. Supra at 199 .

${ }_{10} 48$ Stat. 882 (1934), 15 U.S.C. $\$ 78 c(a)$ (9) (1958).

${ }^{20} 48$ Stat. 882 (1934), I5 U.S.C. $\$ 78 \mathrm{c}$ (a) (10) (1958).

${ }^{21}$ Defendants contended that there was no sale or purchase because the vehicle corporation had been dissolved before the transfer was completed and the management of Consolidated was unaware of the transaction. A novel argument in support of defendants' position was based on plaintiff's allegations that defendants had stolen the stock. Brief for Appellee, pp. 9-1 r.

${ }_{29} 48$ Stat. 882 (1934), 15 U.S.C. $\S 78 c(a)(14)$ (1958).
} 
stock." ${ }^{23}$ Finding that the corporation met the requirements necessary to establish its status as a person intended to be protected by section IO(b) and rule X-IOB-5, the court held that its trustee in bankruptcy was a proper party to proceed under the statute in asserting its tort claim.

Of course, judicial cognizance of a civil remedy in tort when statutorily proscribed conduct results in injury to a member of the class whose interests the statute was enacted to protect, even where the statute prescribes only criminal sanctions, is not a novel concept. ${ }^{24}$ Despite conceptual controversy, ample precedent sustains its applicability in actions arising under section $\mathrm{IO}(\mathrm{b})$ and rule X-rOB-5. ${ }^{25}$ The Hooper

${ }_{23}^{28}$ F.2d at 203 .

${ }^{24}$ Bell v. Hood, 327 U.S. 678 (1946), discussed in Note, Federal Jurisdiction in Suits For Damages Under Statutes Not Affording Such Remedy, 48 Colum. L. Rev. x 090 (1948); Reitmeister v. Reitmeister, x62 F.2d 69x (2d Cir. x 947), discussed in Note, The Use of Criminal Statutes in the Creation of New Torts, 48 ColUM. L. REv. 456 (1948); Restatement, Torts $\$ \S 286-88$ (x935); Lowndes, Civil Liability Created by Criminal Legislation, 16 MiNN. L. REv. 361 (1932); Morris, The Relation of Criminal Statutes to Tort Liability, 46 HARv. L. REv. 453 (1933); Thayer, Public Wrong and Private Action, 27 HARv. L. REv. 317 (1914).

${ }^{25}$ Since neither $\S \mathrm{ro}(\mathrm{b})$ nor rule $\mathrm{X}-\mathrm{roB}-5$ expressly provides for civil liability or a private right of action, this tort concept represents a judicial extension of their applicability. Opponents of extension argue that the purpose of the act, as revealed in $\S 2$, does not comprehend isolated transactions but expresses a primary concern with the operations of professionals in organized markets. See Latty, The Aggrieved Buyer or Seller or Holder of Shares in a Close Corporation Under the S.E.C. Stanttes, I8 Law \& Contemp. Prob. 505, 510 (1953); Comment, 52 MICH. L. Rev. 893 (1954); Note, 64 HARv. L. REv. 1018 (195I). However, there is nothing in the wording of $\S \mathrm{IO}(\mathrm{b})$ which suggests its limitation to organized markets, and defendants have been unsuccessful in asserting this construction in actions arising under the 'section and rule. See, e.g., Kardon v. National Gypsum Co., 69 F. Supp. 512 (E.D. Pa. 1946). This "narrow market" concept appears to conflict with courts" repeated application of $\S \mathrm{I} 7(\mathrm{a})$ of the Securities Act, upon which rule X-1oB-5 is patterned, to private transactions. Bowen v. United States, 153 F.2d 747 (8th Cir.), cert. denied, $32 \mathrm{~S}$ U.S. 835 (1946); United States v. Monjar, 147 F.2d 916 (3d Cir. r944), cert. denied, 325 U.S. 859 ( 1945 ).

Another argument against extension is that rule $X-10 B-5$ was promulgated merely to extend to sellers the protection afforded buyers under $\S x_{7}(a)$ and since courts have not been prone to imply a civil remedy under $\S_{17}(\mathrm{a})$, no such remedy should be available to claimants seeking redress under $\S 1 \mathrm{o}(\mathrm{b})$ and rule $\mathrm{X}-\mathrm{roB}-5$ in the absence of specific provision. See Note, 59 HARv. L. REv. 769, 779 (1946). A comparison of the two statutes, however, reveals that under the 1933 Act the buyer is afforded specific civil remedies under $\S$ I 1 where false registration statements are involved and in connection with false or misleading prospectuses and communications under $\S \mathrm{I2}$, whereas no such all-embracing civil liability provisions exist in the 1934 Act. Section 9 (e) imposes liability for manipulation of securities registered on an exchange, $\S$ i 8 imposes liability for misleading statements in documents filed with the SEC, and $\S x 6(b)$ is concerned with insiders' short-swing profits. Thus, it is apparent that the scope of these sections is 
decision contributes to this body of precedent by emphasizing that the broad purpose of legislation of this type is to provide a means of policing all securities transactions conducted through channels of interstate commerce. By providing redress for a corporation defrauded into issuing stock not regularly traded in any market or exchange this "broad purpose" may well comprehend the extension of these statutory sanctions to any case involving a transfer of securities in which it is alleged that a fraud has been perpetrated by employing either directly or indirectly a means or instrumentality of interstate commerce. ${ }^{26}$ This decision represents a significant step in that direction.

much less comprehensive than that of $\$ \S$ I I and I2 of the $1933 \mathrm{Act}$, which may account for the implication of civil remedies under other sections of the r 934 Act as a complement to its narrow civil liability provisions. For a comparison of the two statutes, see Comment, 59 YALE L.J. I 120 (1950); see also, White, From the Frying Pan into the Fire: Swindlers and the Securities Acts, 45 A.B.A.J. 129 (1959). Thus, § 29(b) which makes contracts in violation of the statute or any rule thereunder "void" has been held to imply a private right of action. Kardon v. National Gypsum Co., 69 F. Supp. 5 12 (E.D. Pa. 1946). Similarly, private rights of action have been recognized under $\S 6(\mathrm{~b})$ : Baird v. Franklin, 141 F.2d 23 \& (2d Cir.), cert. denied, 323 U.S. 737 (1944); \& 7(a)-(d): Remar v. Clayton Sec. Corp., 8I F. Supp. ror 4 (D. Mass. 1949); \$\$ Ir (d) (2) and 17 (a) : Hawkins v. Merrill Lynch, Pierce, Fenner \& Beane, 85 F. Supp. 104 (W.D. Ark. 1949); § I5 (c) (I) : Osborne v. Mallory, 86 F. Supp. 869 (S.D.N.Y. 1949).

${ }^{20}$ See Errion v. Connell, 236 F.2d 447 (9th Cir. 1956), criticized in Comment, 9 Stan. L. Rev. 589 (1957), and Note, 70 Harv. L. Rev. 1309 (1957). 